\title{
Nonprofit advocacy under a third-party government regime: Cooperation or
}

\section{conflict?}

\author{
Bram Verschuere \& Joris De Corte (Ghent University \& University College Ghent, Belgium)
}

\section{Abstract}

Objective. In this article we examine the NPO's commitment to be involved in advocacy activities and the strategies which they rely on to fulfill this expressive role. We question whether the close (financial) relationship between governments and NPO's in Flanders, especially defined in terms of service delivery, will stifle the NPO's advocacy or rather creates new opportunities for giving NPO's a voice in the development of new public policies as well. Method. Using data from a recent large-N survey of Flemish private nonprofit suppliers in four social welfare areas we will conduct multivariate regression analysis to determine which factors could help us to predict the NPO's advocacy behavior. Results. In general, Flemish NPO's indicate a rather low commitment to their advocacy role. However, once NPO's become politically active they rely on a variety of different strategies, especially by utilizing their insider contacts with policy makers and by joining forces into coalitions with other organizations. Conclusion. Our findings suggest that under third-party government regimes NPO's advocacy does not necessarily have to be seen as something conflictual. Instead, advocacy may lead to further cooperation as NPO's become increasingly recognized by governments for their capacity to enrich public policy making from a grassroots perspective.

\section{Introduction}

Flanders (Belgium) is an example of a so-called third-party government regime (Salamon, Anheier et al. 1999; Anheier 2005). Historically, with the expansion of the welfare state, across a broad array of policy arenas nonprofit organizations (NPO) delivered public goods on behalf of government. As a result, Flemish NPO's started to develop synergistic and multidimensional relation ships with governments at all levels (Verschuere and Vancoppenolle 2010). In Flanders, this close relationship is particularly reflected in the NPO's revenue structure. In general, Flemish NPO's nowadays receive up to $75 \%$ of their total revenues from public authorities, predominately in order to deliver social services (Verschuere and Corte 2010). Yet, the nonprofit involvement in the policy process goes beyond the mere implementation of policies. NPO's also take up a more expressive role in contemporary civil societies: preparation and formulation of new social policies (Salamon, Anheier et al. 1999). In this article we will focus on the so-called 
expressive advocacy role of NPO's by analyzing the strategies through which Flemish NPO's exert influence, either directly or indirectly, on decision makers. Data come from a recent large- $\mathrm{N}$ survey which aimed at mapping the relationships between private nonprofit organizations and governments in four social service areas in one particular region (Flanders) of Belgium.

Of particular interest in this article is the question whether this close cooperation with government in terms of service delivery will inevitably stifle the NPO's advocacy activities or will it rather create new opportunities for the NPO's to defend the interest of their members and clients.

There is however some ambiguity among scholars and practitioners in their understanding of the word advocacy. In this article we therefore presume that nonprofit organizations are excellent vehicles for giving voice to unaddressed societal problems (Ross and Osborne 1999; Snavely and Desai 2001; Jenkins 2006). NPO's eventually will translate these issues into political claims and make active interventions on behalf of the constituencies they represent with the explicit goal of influencing public policy (Onyx, Dalton et al. 2008). As such they function as intermediaries with the ability to deepen the ways in which people are represented and participate in democracies (Reid 1999). A substantial amount of empirical and normative scholarship focuses on the levels of nonprofit advocacy in civil societies and the strategies through which NPO's can exert a direct or indirect influence on policymakers (Page 1999; Rees 1999; Grant 2000; Hoefer 2001; Berry and Arons 2003; Andrews and Edwards 2004; Binderkrantz 2005; Child and Gronbjerg 2007; Onyx, Dalton et al. 2008; Schmid, Bar et al. 2008). A second debate discusses the question whether organizational features, and especially the amount of government funding received, might predict whether or not these NPO's will become politically active to fulfill this expressive advocacy role (Smith and Lipsky 1993; Salamon 1995; Boris and Steuerle 1999; Chavez, Stephens et al. 2004; Nicholson-Crotty 2005; Dalton and Lyons 2006; Child and Gronbjerg 2007; Guo and Saxton 2010).

Yet, there seems to be a lack of systematic large-N datasets on NPO's advocacy in so-called third-party government regimes in which the organizations heavily (for more than $50 \%$ of their total income) rely on public funding. In this article, we will address these issues, and test whether the NPO's advocacy behavior is affected differently in societies where government is by far the most dominant funder and regulator regarding the NPO sector, by relying on a large-N dataset of Flemish NPO's. This article has a threefold objective. First, on a descriptive level, we will examine the extent to which Flemish NPO's commit themselves to exert a role as an advocate; secondly we will identify the strategies which they adopt to fulfill this role; and finally we will use multivariate regression analysis to measure the impact of four theoretical frameworks on both this role perception and the strategies which are used to advocate. In the next chapter we will start by presenting the organizations within our dataset. 


\section{Research design and method}

The research population includes Flemish NPO's in four welfare domains; the field of poverty reduction, elderly care, youth care and the integration of ethnic-cultural minorities. All NPO's in this sample share a set of common characteristics. First, as we have mentioned above, the NPO's are active in one of the four selected policy areas. Secondly, all organizations have a permanent and formal character, which is reflected in the presence of paid staff. Thirdly, these NPO's must not belong to the public sector but have a private character. The fact that they receive large amounts of their income from public authorities may thus not prevent them from being self-governed as private entities. Fourthly, we only selected NPO's which embrace the non-distribution constraint, meaning that eventual profits are not distributed among organizational stakeholders but rather are reinvested in improving both quantity and quality of service delivery ${ }^{1}$. Finally, we limit ourselves to organizations which are active in an urban context. We hereby only take into account organizations active in one of the thirteen biggest Flemish cities because we argue that urban NPO's are more likely to be more established organizations which have the capacity to attract and serve customers from surrounding areas as well. Moreover many of the cited societal problems, such as reducing poverty or the integration of ethnic-cultural minorities, will manifest primarily in this urban context. The data presented here are derived from a questionnaire which assessed the relationships between private NPO's and governments at the federal (Belgian) level, the regional (Flemish) level and the local level. This extensive survey was distributed by e-mail to approximately 750 NPO's executives in January 2010. In annex 1 we present the absolute and relative amount of organizations in our sample, both for the total population and divided for the four selected subgroups. We have a total of 255 organizations in our sample, which gives us a fair overall response rate of approximately $33 \%$.

\section{Advocacy by Flemish NPO's}

A first question which is addressed in this article is the extent to which Flemish nonprofit organizations fulfill an advocacy role within civil society. In order to measure this, we refer to the distinction made by Salamon and Anheier (1999) between the two main functions of NPO's activities, delivering social services and giving voice to the needs of their clients and constituents. It is the latter role which converges with the advocacy role and is at the centre of interest in this article. Nonprofit managers were asked to give a subjective assessment of the total resources (organizational time, budget, and staff) which were invested on behalf of these two roles. They did so by positioning their organization on a 5-pointed scale (see annex 2). Hereby, a score of 1 equals a unique focus on service delivery, while a score of 5 indicates that the organization limits itself to a purely advocacy role.

\footnotetext{
${ }^{1}$ This non-distribution constraint is reflected in the organizations' legal status such as the association without profit purpose; associations with a social purpose, private foundations and cooperatives with limited legal liability.
} 
Results for the total population's role perception are shown in the first two columns of table 1 . We see that more than one third $(36,5 \%)$ of all NPO's seems to be only engaged in service delivery. Additionally, for approximately four out five organisations (78,6\%) these service delivering tasks are dominant over the expressive functions. This leaves us with no more than $20 \%$ of the NPO's which dedicate at least half of their organizational resources to their expressive advocacy function (categories 3,4 and 5 ). Finally, only 5,4 $\%$ states that advocacy activities are dominant over service delivering activities (categories 4 and 5).

TABLE 1

Levels of advocacy behavior of Flemish NPO's measured in terms of role perception

\begin{tabular}{|c|c|c|c|c|c|c|}
\hline & \multicolumn{2}{|c|}{ TOT POP } & \multirow[t]{2}{*}{ Poverty } & \multirow{2}{*}{$\begin{array}{l}\text { Elderly } \\
\text { care }\end{array}$} & \multirow{2}{*}{$\begin{array}{l}\text { Youth } \\
\text { care }\end{array}$} & \multirow[t]{2}{*}{ Minorities } \\
\hline & $\%$ & Cum \% & & & & \\
\hline 1 - Only service delivery & $36,5 \%$ & $36,5 \%$ & $39,0 \%$ & $38,6 \%$ & $39,7 \%$ & $16,7 \%$ \\
\hline $\begin{array}{c}2 \text { - More service delivery than } \\
\text { advocacy }\end{array}$ & $42,1 \%$ & $78,6 \%$ & $36,2 \%$ & $45,5 \%$ & $43,8 \%$ & $70,0 \%$ \\
\hline $\begin{array}{l}\text { 3-About the same levels of } \\
\text { service delivery and advocacy }\end{array}$ & $16,0 \%$ & $94,6 \%$ & $17,1 \%$ & $13,6 \%$ & $13,7 \%$ & $23,3 \%$ \\
\hline $\begin{array}{c}\text { 4-More advocacy than service } \\
\text { delivery }\end{array}$ & $3,2 \%$ & $97,8 \%$ & $4,8 \%$ & $2,3 \%$ & $2,7 \%$ & $0,0 \%$ \\
\hline 5-Only advocacy & $2,2 \%$ & $100 \%$ & $2,9 \%$ & $0,0 \%$ & $0,0 \%$ & $6,7 \%$ \\
\hline $\mathbf{N}$ & 252 & & 105 & 44 & 73 & 30 \\
\hline
\end{tabular}

Table 1 also contains the particular scores of the four subgroups within our sample. According to a series of Mann-Whitney tests there are some significant differences concerning organizational role perceptions between the subgroups which are under study in this article (see annex 4). More specific, especially organizations which are active in the sector of ethnic-cultural minorities will indicate a higher commitment to advocacy than for example elderly care or special youth care organizations.

We must however be aware of the fact that this subjective measurement of the role perception is, albeit valuable, also a limited instrument. In the next chapters we will therefore also outline the most frequently used advocacy strategies and some of the organizational mechanisms that might steer the NPO's to become politically active. This approach will allow us to obtain a full picture on the advocacy behavior of Flemish NPO's.

\section{Strategy: How do Flemish NPO fulfill their advocacy role?}

We presented a list (see annex 3) of ten advocacy strategies to only those organizations which confirmed dedicating at least some of their resources to advocacy work (positions 2, 3, 4 or 5 in table 1). That explains why the total $\mathrm{N}$ for this analysis (see table 2) has reduced from 252 to 150 . The scores in table 2 reflect the relative amount of NPO's that specified the use of each individual strategy. 
Individual advocacy strategies have been clustered into three main categories (as shown in table 2); insider strategies, outsider strategies and collective strategies (Grant 2000). Insider strategies are characterized by providing a direct and privileged access to policymakers such as politicians or public administrations (Binderkrantz 2005). In this article we make a double distinction between the targets (politicians versus administrations) and the governmental levels (local versus national) on which they are active. This results in four possible insider strategies. In the case of outsider strategies NPO's try to exert influence those policymakers through indirect strategies of pressures. We have grouped four outsider strategies into two categories. These are on the one hand the two non-conflictual strategies (gaining mass-media coverage and developing information campaigns to the public) and on the other hand two rather conflictual outsider strategies (taking issues into court and organizing protest actions). Finally we also added two other advocacy strategies, forging coalitions with other organizations which are active in the same subfield and becoming a member of sectoral umbrella organizations, which are clustered into a third main category of collective strategies.

TABLE 2

Advocacy strategies used by Flemish NPO's

\begin{tabular}{|c|c|c|c|c|c|c|c|c|}
\hline & & & & TOT POP & ARM & OUD & BJB & MND \\
\hline \multirow[t]{4}{*}{ INSIDER } & -INSIDER & -Politicians & & $62,7 \%$ & $81,0 \%$ & $42,3 \%$ & $48,8 \%$ & $65,2 \%$ \\
\hline & Local & -Adminisrations & & $70,7 \%$ & $77,6 \%$ & $57,7 \%$ & $65,1 \%$ & $78,3 \%$ \\
\hline & -INSIDER & -Politicians & & $34,0 \%$ & $41,4 \%$ & $30,8 \%$ & $30,2 \%$ & $26,1 \%$ \\
\hline & National & -Administrations & & $58,7 \%$ & $56,9 \%$ & $50,0 \%$ & $62,8 \%$ & $65,2 \%$ \\
\hline \multirow[t]{4}{*}{ OUTSIDER } & -OUTSIDER & -Mass-Media & & $42,0 \%$ & $51,7 \%$ & $30,8 \%$ & $37,2 \%$ & $39,1 \%$ \\
\hline & $\begin{array}{c}\text { Non- } \\
\text { conflictual }\end{array}$ & $\begin{array}{l}\text {-Information } \\
\text { campaigns }\end{array}$ & & $50,7 \%$ & $46,6 \%$ & $61,5 \%$ & $46,5 \%$ & $56,5 \%$ \\
\hline & -OUTSIDER & -Protest & & $9,3 \%$ & $15,5 \%$ & $3,8 \%$ & $2,3 \%$ & $13,1 \%$ \\
\hline & Conflictual & -Court & & $4,0 \%$ & $1,7 \%$ & $0,0 \%$ & $7,0 \%$ & $8,7 \%$ \\
\hline \multirow[t]{3}{*}{ COLLECTIVE } & & -Coalitions & & $73,3 \%$ & $72,4 \%$ & $57,7 \%$ & $83,7 \%$ & $73,9 \%$ \\
\hline & & $\begin{array}{l}\text {-Umbrella } \\
\text { organizations }\end{array}$ & & $72,7 \%$ & $74,1 \%$ & $84,6 \%$ & $74,4 \%$ & $52,2 \%$ \\
\hline & & & $\mathbf{N}$ & 150 & 58 & 26 & 43 & 23 \\
\hline
\end{tabular}

Results for the total population show that Flemish nonprofit organizations mainly look at advocacy as a collective effort. More than $70 \%$ of all NPO's is eager to build coalitions with other organizations which are active in the same subfield. These coalitions most often have a temporary character and concentrate organizational time and resources on issues of shared interest. By working together in coalitions or by playing an active role in umbrella organizations NPO's seek to maximize their influence to an extent which would be simply impossible to reach individually. 
Secondly, we may conclude that insider strategies are more frequently used than outsider strategies. Especially local administrations $(70,7 \%)$ and local politicians $(62,7 \%)$ are targeted. Moreover, when we look for differences between the four subsectors within our sample, Mann-Whitney tests reveal that organizations which are active in the poverty sector more heavily rely on the use of these local insider strategies than for example elderly care or youth care organizations (see annex 4). At the national level we see that almost $60 \%$ of all NPO's are working together with public administrations, but only $34 \%$ indicates of having direct access to politicians at these higher (Flemish or federal) governmental levels. Finally, when we turn to the use of outsider strategies we see that the ones with a rather conflictual nature do occur very rarely. In concrete, only 9,3\% of the NPO's has organized in recent times a protest manifestation, while only $4 \%$ has taken issues into court. On the contrary, approximately half of all NPO's regularly tries to influence policymakers in an indirect but non-conflictual way through gaining mass-media coverage (press releases, press conferences, etc) and through launching information campaigns which aim at educating and influencing the public opinion.

\section{Why do NPO act as observed?}

In order to obtain a better understanding of the advocacy behavior of the organizations examined in this study, we use a framework that combines wisdom from institutional theory, resource dependence theory, resource mobilization and rational choice theory.

\section{Organizational field of activity}

Nonprofits which are active in different fields of activity face distinctive public policy environments (Powell 1987). These fields could be considered as broad policy areas in which similar types of social actors, such as nonprofit organizations, operate. More formally, these fields consist of those organizations that, in the aggregate, constitute a recognized area of institutional life (DiMaggio and Powell 1983). In these fields stable patterns of interaction among the totality of relevant actors are produced and exert field-specific institutional forces on their occupants. We therefore expect field of activity to be a useful predictor variable for variation in nonprofit advocacy activity, as nonprofits respond to the unique structures and pressures characteristic of the fields they inhabit. To a certain extent, organizations in the same field will be subject to isomorphism: they tend to show similar organizational behavior (DiMaggio and Powell 1991). Hence we could hypothesize that the commitment of NPO's to exert an advocacy role will vary dependent on the policy field in which the organization is active' (H1a). Furthermore, we could assume that the policy field in which NPO's are active will have an impact on the choice of advocacy strategies' (H1b). In other words, and applied to our empirical sample, playing an advocacy role (and choosing particular strategies to do so) will depend on whether the organizations belongs to the poverty sector, elderly care sector, youth care sector or the sector of integration of ethnic-cultural minorities. 
In general, resource dependence suggests that organizations often become dependent on their environments for resources that are critical for their survival, and this generates uncertainty (Pfeffer and Salancik 2003). This results in a rather conflictual situation between NPO's and governments because NPO's that wish to commit themselves to an advocacy role will fear punishment for certain levels of unwelcome political activity. Resource dependence hereby also operates in a more subtle way because government funding causes changes in nonprofit organizational structure and behavior by redirecting organizational attention and energy away from advocacy and toward administrative activities necessary to sustain the funding source on which they depend (Alexander, Nank et al. 1999). But although both theory and research about nonprofit organizations imply that resource dependence is a relevant explanation, it could be argued that other mechanisms are at work as well. First, resource dependency may be considered as a twoway street (Chavez, Stephens et al. 2004). Even if a nonprofit is dependent on government for its resources, government agencies may also be dependent on that organization to deliver needed services. In situations of such mutual dependence, both government and nonprofits control resources valuable to each other. This could make governments less likely to punish unwelcome political behavior. As we have pointed out before, this could especially be the case in Flanders where governments and NPO's have developed over time an extensive cooperation for public service delivery which has lead to a situation of mutual interdependence (Salamon, Anheier et al. 1999; Verschuere and Vancoppenolle 2010). Secondly, we may refer to the monetary self-interest of NPO's. Hereby, it is argued that NPO's managers whose organizations receive public funding have an objective to protect or enhance these funding streams or otherwise aim at improving working conditions within their respective sectors. In other words, NPO's do not necessarily react passively to their resource environments because they will also try to control and shape these environments. When government is an important part of that environment, as it is the case in Flanders, we might therefore expect political activity, through the use of insider strategies at the different government levels, to increase (Galaskiewicz 1985).

We will hereby hypothesize a negative relationship between the amount of government income at all three levels and the NPO's commitment to fulfill an advocacy role ( $\mathrm{H} 2 \mathrm{a})$. Alternatively, we hypothesize a positive impact of the relative share of gifts in the total NPO's income on this role perception ( $\mathrm{H} 2 \mathrm{~b})$. Thirdly, we expect that due to mechanisms of mutual interdependence and monetaryself interest, NPO's which receive large amounts of income from a government, whether this is at the federal, Flemish or local level, will have an incentive to develop more insider contacts at that same governmental level (H2c). 
By relying on ideas from resource mobilization theory, we could argue that the pursuit of an advocacy role is positively related to the size (e.g. number of full-time employees) of the organization. Larger organizations will have more overall capacities to be involved in a broader array of activities (McCarthy and Zald 1977; Child and Gronbjerg 2007). In the same vein we will also argue that organizations that employ a larger number of highly-educated people will have more chances to fulfill an expressive advocacy role as well because we expect that these functions will be mainly performed by those employees that have the skills to do so (DiMaggio and Powell 1991). This is a kind of organizational professionalization that is necessary for organizations to fulfill an expressive role. Another indicator of organizational capacity may be the relative share of so-called community influentials in the organization's board (Monteduro 2009). This type of board members is of great importance for NPO's advocacy efforts because they represent important parts of civil society (interest groups, unions, midfield organizations), are active within a public administration or are even fulfill a political mandate. In other words, these members have a comprehensive network which can be useful for NPO's to get the things done in a more favorable way. In general, wisdom from resource mobilization thus suggests that only those organizations that have the internal capacity, in terms of (professionalized) staff and having a large amount of community influentials as board members, will be able to take up an expressive advocacy role. This results in the following hypothesis: 'The more capacity the organizations have, in terms of (professionalized) staff and having a network of community influentials at their disposal, the more they will be committed to exert an advocacy role' (H3).

\section{Rational choice: Perceived success of the advocacy strategies applied}

The NPO's choice to rely on a particular advocacy strategy can also be considered as the result of some rational calculating by the organizations. According to rational choice theorists organizations will only have an incentive to act if the costs to obtain a goal are balanced with the benefits which could be gained through this action. In other words, NPO's will make some presuppositions about the potential benefits of pursuing a particular advocacy strategy based on earlier experiences and other factors such as the organizational capacity to conduct these efforts. This kind of behavior (based on logic of consequence, March and Olsen 1996) will make NPO's more eager to choose those strategies which are expected to be the most successful ones. This line of reasoning results in the final hypothesis: 'The use of a particular advocacy strategy will be positively related to the extent to which these strategies are thought to be successful or beneficial for these organizations' (H4). 


\section{Operationalization of the variables}

Four sets of independent variables that can be linked to our theoretical models will be analyzed. The institutional field in which the NPO is active is measured by looking at the four subsectors. We created four dummy variables for the sectors under scrutiny in this article: elderly care, youth care and ethnic-cultural minorities. Resource dependence is measured by looking at four variables: the relative share of funding from national (federal) government, the regional (Flemish) government and the local government in the total NPO's income. Additionally we will also take into account the relative share of private gifts in the total NPO's income, because these gifts and donations are the most important private source of income for most NPO's. All four variables range between 0 (no share of our income comes from this source) to 1 (between $75 \%$ and $100 \%$ of the income stems from this source). Intermediate positions are .20 (source represents less than $10 \%$ of total income), .40 (between 10 and 25\%), .60 (between 25 and $50 \%$ ) and .80 (between 50 and 75\%). Organizational capacity is measured by looking at the total number of FTE in 2009 to measure organizational size. Another measure of organizational capacity (professionalization) is the relative share of full-time equivalents (FTE) with a master's degree and the relative share of full-time equivalents with a bachelor's degree in the total staff population (FTE). Finally we look at the relative share of community influentials in the organization's board. We asked respondents to assign each member of their board to one of the four categories which we have presented them based on the member's professional background or the particular expertise they may provide for the organization. These four categories were: members which are active within the organization; members with particular experience in managing an organization; members with specific experience in terms of financial management, $H R, P R$, etc; and finally members which represent important parts of civil society such as midfield organizations; unions, political parties, etc. This last category can also be described as the so-called 'community influentials'. The relative share of these community influentials in the organization's board is then calculated by dividing the number of community influentials by the total board members as indicated by the organizations. This results in a score between 0 and 1.

For measuring whether the choice of advocacy strategy is a matter of rational calculation we asked survey respondents not only to what extent they relied on each strategy but likewise we asked them to indicate the extent all of these strategies are thought to be successful on a 4-point scale (ranging from 1 to 4). These scores were recoded in order to obtain a scale that ranges between 0 and 1: a score of 1 (not successful at all) became 0; a score of 2 (rather not successful) became 0,33; a score of 3 (rather successful) became 0,66; and a score of 4 (very successful) became 1 .

These models are tested on a total of six dependent variables: the CEO's subjective interpretation of the organization's role perception as indicated on a 5-point scale (see table 1), and the five categories of advocacy strategies which NPO's have at their 
disposal (see table 2). The original values of our dependent variables are recoded into indexes with scores between 0 and 1 . For the NPO's role perception we recoded the original value 1 (only focus on service delivery) in a score of 0 , a score of 2 (more service delivery than advocacy) then became 0,25; a score of 3 (equal efforts for service delivery and advocacy) became a score of 0,50; a score of 4 (more advocacy than service delivery) became 0,75 and finally a score of 5 (focus only on advocacy) became a score of 1 . We did something similar for all five categories of advocacy strategies. The original values all had a score between 1 and 4 . We therefore carefully recoded a score of 1 (this advocacy strategy is never used) into a score of 0 ; the original score 2 (this advocacy strategy is rarely used) into 0,33; a score of 3 (this advocacy strategy is used occasionally) into 0,66 ; and finally a score of 4 (this advocacy strategy is very often used) became a score of 1.

In annex 3, the descriptive statistics of the dependent variables can be found. In the last column we also added the cronbach's alpha (measure for internal consistency of the scale) for the five categories of advocacy strategies that were constructed for this article.

\section{Empirical results}

Table 3 shows the results of the multiple regression analyses whereby the impact of four theoretical models (rows) is tested on two sets of dependent variables (columns): the role perception of nonprofit organizations and the five advocacy strategies of these NPO's. The forward method is used in order to identify variables which have a significant impact on the six dependent variables. All relationships which turned out to be significant are marked in bold (standardized beta-coefficients). As shown in table 3 the NPO's role perception could adequately be predicted by relying on both resource dependence and resource mobilization frameworks. Yet, these results do not correspond to what we had hypothesized. Receiving income from local government seems to have a relatively strong, but positive, impact on the extent to which NPO's consider themselves as being advocacy organizations. This finding is contrary to what resource dependence theory would have suggested ( $\mathrm{H} 2 \mathrm{a})$. It should however also be noted that federal and especially Flemish income, which actually is the biggest funding source for most NPO's, do not have a significant negative (nor positive) impact on the NPO's role perception.

Additionally, we found some support for the positive impact of receiving income from gifts and donations on the NPO's willingness to exert an advocacy role in civil society ( $\mathrm{H} 2 \mathrm{~b})$. When we turn to resource mobilization theory we see, in spite of our initial hypothesis (H3), a rather negative impact of organizational capacity (in terms total numbers of FTE) on the role perception of NPO's. In other words, we may state that in Flanders especially the smaller organizations are more likely to be engaged in advocacy work. 
Finally, we found no effect of field of activity on the NPO's commitment to fulfill an advocacy role (H1a). The extent to which NPO's rely on the use of insider strategies at the local level could, as hypothesized $(\mathrm{H} 2 \mathrm{c})$, be predicted by the amount of income received from that same local government. This is however not the case when we turn to the national governmental levels. Hereby, receiving income from federal or Flemish government does not have a significant impact on the development of insider strategies at those governmental levels. Finally we found that the rational choice framework seems to be a very predictive model for determining NPO's advocacy activities. There is indeed a strong effect on the use of all five advocacy strategies and the perceived success attached to those particular strategies (H4).

TABLE 3

Standard coefficients (Bèta) of multiple regression models for role perception and strategies used by Flemish NPO's

\begin{tabular}{|c|c|c|c|c|c|c|}
\hline & ROLE & STRATEGIES & & & & \\
\hline & $\begin{array}{c}\text { Role } \\
\text { perception }\end{array}$ & Insider local & Insider national & $\begin{array}{l}\text { Outsider non- } \\
\text { conflictual }\end{array}$ & $\begin{array}{l}\text { Outsider } \\
\text { conflictual }\end{array}$ & $\begin{array}{l}\text { Collective } \\
\text { strategies }\end{array}$ \\
\hline \multicolumn{7}{|l|}{ Field of activity } \\
\hline -elderly care & $.094(.428)$ & $-.063(.409)$ & $-.073(.412)$ & $.082(.408)$ & $-.032(.725)$ & $-.021(.820)$ \\
\hline -Youth care & $-.136(.060)$ & $-.110(.137)$ & $-.189(* *)$ & $-.066(.500)$ & $.016(.857)$ & $-.041(.652)$ \\
\hline - Minorities & $.099(.332)$ & $.127(.078)$ & $.085(.347)$ & $.014(.888)$ & $-.036(.691)$ & $-.004(.969)$ \\
\hline \multicolumn{7}{|l|}{$\begin{array}{l}\text { Resource } \\
\text { dependence }\end{array}$} \\
\hline -Income federal & $-.046(.532)$ & $-.084(.252)$ & .001 (.990) & $-.062(.532)$ & $-.084(.358)$ & $-.083(.361)$ \\
\hline - Income Flemish & $.019(.798)$ & $.107(.162)$ & $.094(.273)$ & $-.143(.140)$ & $.006(.945)$ & $.130(.151)$ \\
\hline - Income local & $.318(* * *)$ & $.219(* * *)$ & $-.031(.731)$ & $-.090(.361)$ & $.057(.527)$ & $-.121(.187)$ \\
\hline - Income gift & $.180(* *)$ & $-.132(.069)$ & $-.053(.538)$ & $.131(.180)$ & $.030(.745)$ & $-.010(.187)$ \\
\hline \multicolumn{7}{|l|}{$\begin{array}{l}\text { Resource } \\
\text { mobilization }\end{array}$} \\
\hline -FTE 2009 & $-.211(* * *)$ & $.049(.503)$ & $.005(.956)$ & $-.079(.432)$ & $-.065(.484)$ & $-.012(.891)$ \\
\hline $\begin{array}{l}\text {-Share of Bachelors in } \\
\text { total FTE } 2009\end{array}$ & $-.072(.332)$ & $-.113(.123)$ & $-.032(.711)$ & $-.086(.385)$ & $.148(.105)$ & $.050(.580)$ \\
\hline $\begin{array}{l}\text { - Community } \\
\text { influentials }\end{array}$ & $-.032(.666)$ & $.021(.776)$ & $-.063(.463)$ & .009 (.925) & $-.070(.457)$ & $.025(.787)$ \\
\hline \multicolumn{7}{|l|}{ Rational choice } \\
\hline $\begin{array}{l}\text {-Perceived success of } \\
\text { advocacy strategy }{ }^{2}\end{array}$ & & $.642(* * *)$ & $.655(* * *)$ & $.535(* * *)$ & $.838(* * *)$ & $.536(* * *)$ \\
\hline Total adjusted $\mathbf{R}$ & $0.192(.000)$ & .548 & .470 & .275 & .695 & .279 \\
\hline square & & $(.000)$ & $(.000)$ & $(.000)$ & $(.000)$ & $(.000)$ \\
\hline $\mathrm{N}$ & 252 & 150 & 150 & 150 & 150 & 150 \\
\hline & $* * * \mathrm{p}<0.01$ & $p<0.05$ (two-t & & & & \\
\hline
\end{tabular}

\section{Discussion and conclusion}

Our results show that the scope of political advocacy by Flemish NPO's was found to be rather moderated and limited, as it was perceived by the NPO's managers, especially when compared to efforts made in terms of service delivery. In others words, while still more than $60 \%$ of the NPO's is involved in some form of advocacy, only $20 \%$ of them also dedicates significant organizational

\footnotetext{
${ }^{2}$ Scores in this table reflect the perceived success for the use of the particular advocacy strategy that is described in each column.
} 
resources (time, money, staff, etc) to these tasks. These results correspond well with recent studies amongst for example Spanish or Israeli nonprofit organizations (Fuertes-Fuertes and Maset-Llaudes 2007; Schmid, Bar et al. 2008). In that respect we may consider the NPO's attitude towards advocacy as being ambivalent, meaning that many NPO's do engage in some form of expressive work, but likewise only few organizations have these activities as their primary focus (Anheier 2005; Child and Gronbjerg 2007). As we have mentioned earlier, Flemish NPO's do have a long-term tradition of being recognized and financed for delivering public services under a third-party government regime. The analysis of the roles Flemish NPO's play in the public sphere, be it as service deliverers or as advocates of interests, can however not only rely on the measure of the CEO's interpretation of his or hers organization's role. Further analysis of advocacy strategies may yield more nuanced findings. During our analyses, it then became clear that the picture of Flemish NPO's as being predominately service-oriented is less black-and-white than might be presumed.

NPO's do have a wide variety of different advocacy strategies at their disposal once they decide to become politically active. In other words, NPO's will make deliberate choices in order to influence policymakers in a direct, indirect or in a collective way. The table in annex 5 shows several positive correlations between different categories of advocacy strategies. This implies that although differences do occur in the scope and intensity in NPO's preference to use one strategy or another, these categories are not mutually exclusive (see also Binderkrantz 2005). We also found that especially collective strategies are frequently used. Building and maintaining strong coalitions with other organizations is seen as a key factor for successful NPO advocacy (Rees 1999; Hoefer 2001; Andrews and Edwards 2004; Gormley and Comrot 2006; Nicholson-Crotty 2007; Onyx, Armitage et al. 2010). Coalitions are hereby valued as important sources of information regarding policy and program changes and as providers of political cover to organizations that want to dispute government positions (Plitt-Donaldson 2007).

Concerning the explanations of why NPO's will choose a particular advocacy strategy, we found that the rational choice perspective is by far the most important framework. This would imply that NPO's deliberately choose strategies of which they think that they will enhance their advocacy efforts. The capacity of the NPO (resource mobilization), their field of activity, and their funding source does not seem to play a role in the NPO's choice for advocacy strategies.

Finally, we found that NPO's that receive relatively more income from local government and from private gifts, and also the smaller NPO's, perceive themselves more often as advocates. These findings are contrary to what we expected from resource dependence and resource mobilization theories. These findings could be explained, however. It could be that NPO's that fulfill an advocacy role do not consider this role as something that yields a conflictual relationship with government. Resource dependence theory implicitly assumes conflict: 'don't bite the hand that feeds you', because that may result in NPO's losing an essential part of their financial 
resources (Smith and Lipsky 1993; Alexander, Nank et al. 1999; Maddison and Denniss 2005; Child and Gronbjerg 2007; FuertesFuertes and Maset-Llaudes 2007; Schmid, Bar et al. 2008; Guo and Saxton 2010). But in societies with a third-party government regime, as it is the case in Flanders, we can assume that government-nonprofit relations are based on cooperation rather than on conflict: NPO's that mainly deliver services, and still perform some advocacy functions, may consider advocacy as something that must improve the relationship with government. This is beneficial for both NPO and government. NPO's with good relations with government secure funding, and government may rely on the NPO's potential to enrich the public policy making process from their grassroots perspective. Our evidence shows that NPO's often rely on insider strategies to fulfill their advocacy role: direct contacts with politicians and public administrators. It is not unrealistic to assume that government - NPO agreements primarily made for facilitating service delivery may place some NPO's in a more favorable position to develop insider contacts. These contacts may pave the road for further cooperation in other phases of the policy cycle as well, such as for participation in policy formulation or policy evaluation. In that case, instead of making a strict division between NPO's performing or service delivery or expressive advocacy roles, it rather could be argued that these two roles inextricably are bound up with each other.

In Flanders, these forms of government - NPO cooperation become more commonplace. A good example is the Decree on Local Social Policy. This Decree is a recent initiative (2004) which aims at fostering cooperation between local governments and private NPO's, not only on an operational level but also on a strategic level, by involving NPO's in the development of local social policies: NPO's are expected to 'think' with local government about local social policy. Our finding that local government funding has a positive and significant impact on the NPO's perception of having an advocacy role can be interpreted in the context of the increased cooperation between NPO's and local government since the establishment of the new decree. In general, we may therefore conclude that advocacy does not necessarily have to be seen as something 'conflictual' in the interaction between governments and private nonprofit organizations. Especially in third party government systems, in which government and NPO have a tradition in cooperation in public service delivery, 'advocacy' may be something to further improve existing relations.

\section{REFERENCES}

Alexander, J., R. Nank, et al. (1999). Implications of welfare reform: Do nonprofit survival strategies threaten civil society?, Sage Publications Inc.

Andrews, K. T. and B. Edwards (2004). "Advocacy organizations in the US political process." Annual Review of Sociology 30: $479-506$. Anheier, L. (2005). The Nonprofit Sector: Approaches, Management, Policy. New York, Routlegde.

Berry, J. and D. Arons (2003). A voice for nonprofits. Washington, DC, Brookings Institution Press.

Binderkrantz, A. (2005). "Interest group strategies: Navigating between privileged access and strategies of pressure." Political Studies 53(4): 694-715.

Boris, E. and C. Steuerle (1999). Nonprofits and government: Collaboration and conflict. Washington, DC, Urban Institute. 
Chavez, M., L. Stephens, et al. (2004). "Does government funding suppress nonprofit's political activity? ." American Sociological Review 69(2).

Child, C. D. and K. A. Gronbjerg (2007). "Nonprofit advocacy organizations: Their characteristics and activities." Social Science Quarterly 88(1): 259-281.

Dalton, L. and Lyons (2006). Representing the disadvantaged in Australian Politics: the role of advocacy organizations. Democratic audit of Australia, Report no 5.

DiMaggio, P. and W. Powell (1983). "The iron cage revisited: Institutional isomorphism and collective rationality in organizational fields." American Sociological Review 48(2).

DiMaggio, P. and W. Powell (1991). The new institutionalism in organizational analysis. Chicago, University of Chicago Press.

Fuertes-Fuertes, L. and Maset-Llaudes (2007). "Exploring Spanish Nongovernmental Organizations for development: an empiral approach." Nonprofit and voluntary sector Quarterly 36.

Galaskiewicz, J. (1985). "Interorganizational relations." Annual review of Sociology 11.

Gormley, W. and H. Comrot (2006). "The strategic choices of child advocacy groups." Nonprofit and Voluntary Sector Quarterly 35(1).

Grant, W. (2000). Pressure groups and British politics. London, Macmillan.

Guo, C. and G. D. Saxton (2010). "Voice-In, Voice-Out: Constituent Participation and Nonprofit Advocacy." Nonprofit Policy Forum 1(1).

Hoefer, R. (2001). "Highly effective human services interest groups: Seven key practices." Journal of Community Practice 9(2).

Jenkins, L. (2006). Nonprofit Organizations and Political Advocacy. The Nonprofit Sector: a research handbook. Powell and Steinberg. New Heaven \& London, Yale University Press.

Maddison, S. and R. Denniss (2005). "Democratic constraint and embrace: Implications for progressive non-government advocacy organisations in Australia." Australian Journal of Political Science 40(3): 373-389.

March, J. and J. Olsen. (1996). Institutional Perspectives on Political Institutions. Governance 93:147-264.

McCarthy, J. and M. Zald (1977). "Resource mobilization and social movements: A partial theory." American Journal of Sociology 82(6).

Monteduro (2009). Do nonprofit boards matter for innovation? An empirical analysis of grant-giving foundations. EGPA. St Julians, Malta.

Nicholson-Crotty, J. (2007). "Politics, policy, and the motivations for advocacy in nonprofit reproductive health and family planning providers." Nonprofit and Voluntary Sector Quarterly 36(1).

Nicholson-Crotty, L. (2005). The stages of nonprofit advocacy. PhD, Texas A\&M University.

Onyx, J., L. Armitage, et al. (2010). "Advocacy with gloves on: The 'Manners' of Strategy used by some third sector organizations undertaking advocacy in NSW and Queensland." Voluntas 21.

Onyx, J., B. Dalton, et al. (2008). "Implications of government funding of advocacy for third-sector independence and exploration of alternative advocacy funding models." Australian Journal of Social Issues 43(4): 631-648.

Page, E. (1999). "The insider/outsider distinction: an empirical investigation." British Journal of Politics and International Relations $1(2)$.

Pfeffer, J. and G. Salancik (2003). The external control of organizations: A resource dependence perspective (2nd ed.). Stanford, CA, Stanford University Press.

Plitt-Donaldson (2007). "Advocacy by nonprofit human service agencies: Organizational factors as correlates to advocacy behavior." Journal of Community Practice 15(3).

Powell, W. (1987). The nonprofit sector: A research handbook. New Heaven, CT, Yale University Press.

Rees, S. (1999). "Strategic choices for nonprofit advocates." Nonprofit and Voluntary Sector Quarterly 28(1): 65-73.

Reid, E. (1999). Nonprofit advocacy and political participation. Nonprofits and government: collaboration and conflict. E. Boris and C. Steuerle. Washington DC, Urban Institute Press.

Ross and Osborne (1999). "Making a reality of community governance. Structuring government-voluntary sector relationships at the local level." Public Policy and Administration 14(49): 49-61.

Salamon, L. (1995). Partners in Public Service: Government-nonprofit relations in the modern welfare state. Baltimore, John Hopkins University Press.

Salamon, L., Anheier, et al. (1999). Global Civil Society: Dimensions of the Nonprofit sector.

Schmid, H., M. Bar, et al. (2008). "Advocacy Activities in Nonprofit Human Service Organizations." Nonprofit and Voluntary Sector Quarterly 37(4): 581-602.

Smith, L. and Lipsky (1993). "Nonprofits for hire: The welfare state in the age of contracting." Cambridge, MA, Harvard University Press: In: Anheier (2005), Nonprofit Organizations: Theory, Management, Policy.

Snavely, K. and U. Desai (2001). "Mapping local government-nongovernmental organization interactions: A conceptual framework." Journal of Public Administration Research and Theory 11(2): 245-263. 
Verschuere and D. Corte (2010). The relationship between local governments and private nonprofit organizations: Preliminary results from an empirical study in 13 Flemish cities. IRSPM-conference. Bern.

Verschuere, B. and D. Vancoppenolle (2010). Welzijn in Vlaanderen: Beleid, bestuurlijke organisatie en uitdagingen. Brugge, Die Keure.

\section{Annexes}

\section{ANNEX 1: Sample of organizations and distribution in the four sub-sectors}

\begin{tabular}{cccccc}
\hline & Total & Poverty & Elderly care & Youth care & Minorities \\
\hline $\mathbf{N}$ & 255 & 107 & 45 & 73 & 30 \\
$\%$ & $100 \%$ & $42,2 \%$ & $17,6 \%$ & $28,5 \%$ & $11,7 \%$ \\
\hline
\end{tabular}

\section{ANNEX 2: Survey questions}

Q1 - "Your organization can rely on different tactics in order to influence public policy. Please indicate in the table below the extent to which you have used each particular advocacy strategy"

\section{STRATEGIES}

INSIDER INSIDER Local

INSIDER

National

OUTSIDER OUTSIDER

Nonconflictual

OUTSIDER Conflictual

COLLECTIEF
-Developing and maintaining direct contacts with politicians at the local level.

-Developing and maintaining direct contacts with administrations at the local level.

-Developing and maintaining direct contacts with politicians at the higher (federal or Flemish) level.

-Developing and maintaining direct contacts with administrations at the higher (federal or Flemish) level.

-Distributing organizational views through press releases, press conferences, writing opinions in newspaper, maintaining informal contacts with journalists, etc.

-Developing information campaigns in order to make the general public or particular groups within civil society aware of organizational viewpoints.

-Organizing protest actions, strikes, sit-ins, etc.

-Taking government decisions into court.

-Forging coalitions with other organizations which are active in the same subfield and have similar interests to defend.

-Playing an active role in sectoral umbrella organizations

\section{FREQUENCY}

1

Never

2

Very

rarely

Occasio Often

nally

4

ften

. 
ANNEX 3: Descriptive statistics dependent and independent variables

\begin{tabular}{|c|c|c|c|c|c|c|}
\hline & $\mathbf{N}$ & Minimum & Maximum & Mean & $\begin{array}{l}\text { Standard } \\
\text { deviation }\end{array}$ & $\begin{array}{c}\text { Cronbach's } \\
\text { Alpha }\end{array}$ \\
\hline Role perception & 252 & 0 & 1 & .2302 & .2278 & I \\
\hline Insider local & 150 & 0 & 1 & .6268 & .2761 & .699 \\
\hline Insider national & 150 & 0 & 1 & .4668 & 2688 & 621 \\
\hline $\begin{array}{l}\text { Outsider non- } \\
\text { conflictual }\end{array}$ & 150 & 0 & 1 & .4620 & .2373 & .378 \\
\hline $\begin{array}{l}\text { Outsider } \\
\text { conflictual }\end{array}$ & 150 & 0 & 1 & .1144 & .1493 & .200 \\
\hline $\begin{array}{l}\text { Collective } \\
\text { strategies }\end{array}$ & 150 & 0 & 1 & .6624 & .2497 & .441 \\
\hline $\begin{array}{l}\text { Succes insider } \\
\text { local }\end{array}$ & 131 & 0 & 1 & .6052 & .2227 & .664 \\
\hline $\begin{array}{l}\text { Success insider } \\
\text { national }\end{array}$ & 111 & 0 & 1 & .5287 & .2213 & .553 \\
\hline $\begin{array}{l}\text { Success outsider } \\
\text { non-conflictual }\end{array}$ & 111 & 0 & 1 & 5062 & .1956 & .497 \\
\hline $\begin{array}{l}\text { Success outsider } \\
\text { conflictual }\end{array}$ & 62 & 0 & 1 & .2214 & .2224 & .372 \\
\hline $\begin{array}{l}\text { Success collective } \\
\text { strategies }\end{array}$ & 129 & 0 & 1 & .6768 & .2039 & .508 \\
\hline
\end{tabular}

\begin{tabular}{lccccc}
\hline & N & Minimum & Maximum & Mean & $\begin{array}{c}\text { Standard } \\
\text { deviation }\end{array}$ \\
\hline Income federal & 237 & 0 & 1 & .1654 & .2804 \\
Income Flemish & 237 & 0 & 1 & .6034 & .3799 \\
Income Local & 237 & 0 & 1 & .2270 & .2742 \\
Income Gift & 237 & 0 & 1 & .1367 &. .2022 \\
$\begin{array}{l}\text { FTE 2009 } \\
\text { Share of Masters }\end{array}$ & 237 & 0 & 1200 & 31.82 & .266 .61 \\
in total FTE & 209 & 0 & 1 & .2374 & .2561 \\
$\begin{array}{l}\text { Share of } \\
\text { Bachelors in total }\end{array}$ & 211 & 0 & 1 & .4674 & .2920 \\
$\begin{array}{l}\text { FTE } \\
\text { Share of } \\
\text { community }\end{array}$ & 217 & 0 & 1 & .2952 & .2967 \\
influentials in & & & & & \\
board & & & & & \\
& & & & & \\
\hline
\end{tabular}


ANNEX 4:

In the table below results are presented for Mann-Whitney tests which were conducted in order to determine whether or not there were significant differences between the four selected subsectors for the main independent variables.

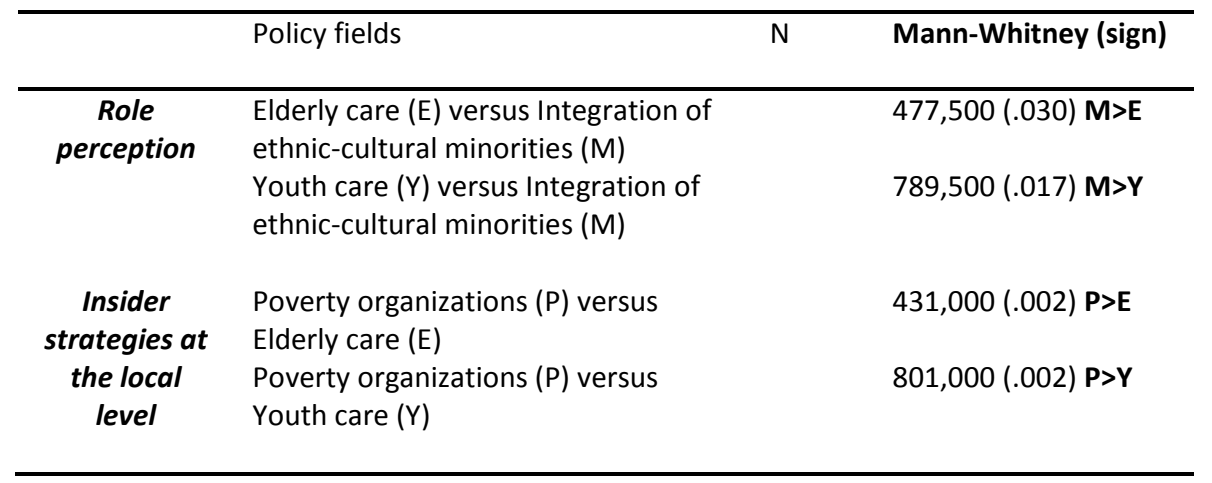




\section{ANNEX 5}

The table below shows the correlations (Pearson's) which we have found between the all dependent and independent variables which were used to conduct the multiple regression analysis $(* \mathrm{p}<.05 / * * \mathrm{p}<.001)$.

\begin{tabular}{|c|c|c|c|c|c|c|c|c|c|c|c|c|c|c|c|c|c|c|c|}
\hline & (1) & (2) & (3) & (4) & (5) & (6) & (7) & (8) & (9) & (10) & (11) & (12) & (13) & (14) & (15) & (16) & (17) & (18) & (19) \\
\hline Role perception (1) & 1 & -009 & -.061 & $.248^{* *}$ & $.251 * *$ & .054 & -121 & -.121 & $.259 * *$ & $.186 * *$ & $-237 * *$ & .106 & .003 & -.044 & -.043 & $-.224 *$ & .153 & $.393 * *$ & .000 \\
\hline Insider local (2) & - & 1 & $.243 * *$ & .144 & .094 & .041 & .062 & -.125 & $.516^{* *}$ & $-.220^{* *}$ & .137 & -.059 & -.160 & .079 & $.675 * *$ & -.016 & .029 & -.189 & -.002 \\
\hline Insider national (3) & - & - & 1 & $.265^{* *}$ & $.185 *$ & $.283^{* *}$ & .096 & $.194^{*}$ & -.024 & $-.230 * *$ & .113 & $.197^{*}$ & -.034 & -.074 & $.224^{*}$ & $\begin{array}{c}.646 \\
* *\end{array}$ & $.235^{*}$ & .137 & .158 \\
\hline $\begin{array}{l}\text { Outsider non-conflictual } \\
\text { (4) }\end{array}$ & - & - & - & 1 & $\begin{array}{c}.360 \\
* *\end{array}$ & .154 & .035 & -.080 & .007 & .106 & -.154 & $.180 *$ & -.102 & -.074 & .058 & .112 & $.575 * *$ & $.278^{*}$ & .008 \\
\hline Outsider conflictual (5) & - & - & - & - & 1 & .093 & $\begin{array}{c}- \\
.122\end{array}$ & -.109 & .124 & $.188^{*}$ & .138 & .044 & .022 & -.077 & .023 & .106 & .098 & $.833 * *$ & -.069 \\
\hline Collective strategies (6) & - & - & - & - & - & 1 & .007 & $.243^{* *}$ & -.035 & -.154 & .140 & .042 & .042 & .015 & .066 & $.200^{*}$ & .152 & .122 & $\begin{array}{c}.639 \\
* * \\
\end{array}$ \\
\hline Income federal (7) & - & - & - & - & - & - & 1 & $\begin{array}{c}- \\
.385 * * \\
\end{array}$ & -.089 & $-.161^{*}$ & $.241 * *$ & -.109 & $-.175 *$ & -.011 & .006 & -.046 & .098 & -.148 & .123 \\
\hline Income Flemish (8) & - & - & - & - & - & - & - & 1 & $\begin{array}{c}- \\
.209 * * \\
\end{array}$ & $-.194 * *$ & $.237 * *$ & .087 & $.172 *$ & -.093 & -.094 & $.218^{*}$ & .005 & .006 & .088 \\
\hline Income Local (9) & - & - & - & - & - & - & - & - & 1 & .049 & -.028 & -.091 & -.016 & .085 & $.346 * *$ & $\begin{array}{c}-.266 \\
* *\end{array}$ & -.073 & -.143 & -.143 \\
\hline Income gift (10) & - & - & - & - & - & - & - & - & - & 1 & $-.302^{*}$ & .034 & .129 & $-.166 *$ & -.123 & -.169 & -.017 & .245 & -.105 \\
\hline FTE 2009 (11) & - & - & - & - & - & - & - & - & - & - & 1 & $-325^{* *}$ & $-235^{* *}$ & -.011 & .046 & .050 & -.184 & -.199 & .077 \\
\hline Masters in total FTE (12) & - & - & - & - & - & - & - & - & - & - & - & 1 & $-.222^{*}$ & .038 & .043 & .160 & .153 & .251 & .025 \\
\hline Bachelors in total FTE (13) & - & - & - & - & - & - & - & - & - & - & - & - & 1 & $-.156^{*}$ & -.071 & .046 & -.198 & -.154 & .014 \\
\hline $\begin{array}{l}\text { community influentials } \\
\text { (14) }\end{array}$ & - & - & - & - & - & - & - & - & - & - & - & - & - & 1 & .143 & -.054 & -.139 & -.223 & -.112 \\
\hline Success Insider local(15) & - & - & - & - & - & - & - & - & - & - & - & - & - & - & 1 & $.299 * *$ & .071 & -.058 & .176 \\
\hline $\begin{array}{l}\text { Success Insider national } \\
\text { (16) }\end{array}$ & - & - & - & - & - & - & - & - & - & - & - & - & - & - & - & 1 & $.240^{*}$ & .186 & $\begin{array}{c}.304 \\
* *\end{array}$ \\
\hline $\begin{array}{l}\text { Success outsider non- } \\
\text { conflict (17) }\end{array}$ & - & - & - & - & - & - & - & - & - & - & - & - & - & - & - & - & 1 & .215 & $\begin{array}{l}.299 \\
* *\end{array}$ \\
\hline $\begin{array}{l}\text { Success outsider } \\
\text { conflictual (18) }\end{array}$ & - & - & - & - & - & - & - & - & - & - & - & - & - & - & - & - & - & 1 & 056 \\
\hline Success collective(19) & - & - & - & - & - & - & - & - & - & - & - & - & - & - & - & - & - & - & 1 \\
\hline
\end{tabular}

